\title{
Tax Aspects of Mergers and Cross-Border Mergers ${ }^{\#}$
}

\author{
Marcela Žárová* - Jana Skálová ${ }^{* *}$
}

\section{Introduction}

Over the past ten years, it has been possible to recognize European effort to promote cross-border mergers, as one of the possibilities to support free movement of capital cross borders. Despite this fact, companies use this form of merge rather rarely. The aim of this article is to monitor numbers of realized cross-border mergers in the Czech Republic and then to analyze tax aspects of domestic mergers and crossborder ones in the European Union. The article concentrates on tax affects of revaluation of assets, possibilities to take over tax losses and to deny benefits from other tax in compliance with European Directives. As above-mentioned topics are regulated by Directives in the EU and transposition of Directives might differ, European Court of Justice is asked for treatment. In the article, there are selected those judicial acts that show the direction of unifying the analyzed application of tax rules.

\section{Literature Overview and Methodology}

There are very unique papers on cross-border mergers such as paper on cross-border mergers and acquisitions concerning financial and institutional forces (Coeurdacier, 2009) or paper assessing the impact of the main forces driving cross-border mergers, where a unique database for 10 acquiring manufacturing sectors and 10 acquiring service sectors located in 21 deferent countries targeting foreign assets in 31 deferent

\# The contribution is processed as one of the outputs from the research project of the Faculty of Finance and Accounting, University of Economics in Prague, which is carry out within the Institutional support of University of Economics in Prague number IP 100040.

doc. Ing. Marcela Žárová, CSc. - Assistant Professor; Department of Fnancial Accounting and Auditing, University of Economics, Prague, W. Churchill Sq. 4, 130 67 Praha 3, <zarova@vse.cz>,

** Ing. Jana Skálová, Ph.D. - Research Assistant; Department of Fnancial Accounting and Auditing, University of Economics, Prague, W. Churchill Sq. 4, 13067 Praha 3, <jana.skalova@vse.cz >. 
Žárová, M. - Skálová, J.: Tax Aspects of Mergers and Cross-Border Mergers.

host countries (over the 1985 - 2004 period) were constructed (Oestreicher 2010).

Over the past seven years, professional literature has included a number of references to a specific type of ownership transactions between companies, which are referred to as cross-border acquisitions and mergers. German literature quite frequently deals with the depiction of mergers from the accounting point of view; e.g. Knüppel (2007); with Kulenkamp (2009) and Behrens (2007) examining the EU directives relating to cross-border mergers.

In the Czech accounting literature, Vomáčková (2012) describes in details accounting aspects of mergers. Analysis of Czech accounting system development and impact of EU regulation on Czech accounting system is described by Ištvánfyová a Mejzlík (2009), while Žárová (2006, 2008) addresses Czech accounting reforms as a necessary background for cross-border mergers realization. Specific issues of deferred taxes as a consequence of revaluation for mergers' purposes is analysed by Pelák (2010).

Accounting and tax procedures realized by permanent establishment, that arises as a consequence of cross-border merge is addressees by Roubičková (2011). The questions of important conditions for realization of cross-border merge in the Czech environment are analyzed by Sklenár and Roubíčková (2011). An overview of EU Directive on cross-border merge transposition into EU member states legislation is provided by Skálová and Mejzlík (2012). Impact of important amendment of Act for cross-border merge was analysed by Trnka, Dugová (2013). Tax effects of cross-border merge are mentioned only marginally, mostly in works on impacts of EU Directives on corporation tax Vítek (2013), as this issue is not frequently described as the main topic.

Differences in legal regulation of mergers and particularly differences in approaches to their accounting treatment between the individual countries of the European Union have already been dealt with in the professional literature in the past (Žárová, Skálová, 2012). Professional research at the University of Economics in Prague contributed also to addressing the accounting treatment in the Czech Republic, which was integrated in an amendment to the Transformations Act (Žárová 2013).

The method of description is used in this paper to describe situation on cross-border mergers in the Czech Republic including transposition of 
Directive on mergers. Information on internal tax conditions for mergers in different countries has been allocated using a questionnaire.

The questionnaire was made, during the research, containing questions concerning the accounting approaches used in mergers, the approach to valuation and some of the tax contexts of mergers. The questions were mainly posed as closed questions, while some of them were posed as opened ones. The questionnaire was sent to consulting firms from the Crowe Horwath network. It is a network of independent consulting firms, which are among the medium sized firms on the market. Professional knowledge of the issue was assumed and experiences with these transactions were on the part of this group of respondents. Questions were aimed at the determination of 10 crucial characteristics from the national accounting regulatory system and the tax regulatory system, which were the subjects of research.

The questionnaires were sent to 27 European countries. The filled questionnaires were received back from the following countries: Belgium, Czech Republic, France, Cyprus, Hungary, Norway, Poland, Austria, Romania and Slovakia. $37 \%$ of the questionnaires sent were returned.

For the purpose of this paper, there were used research results from following areas:

- Whether there exists a duty to continue in tax depreciation within the framework of inland mergers, or in cross-border mergers;

- Whether there exists a duty to tax the difference between the real value of the property, and its original tax base in the transfer of property and liabilities across borders as a consequence of a merger;

- The possibility of transferring tax losses from the expired firm to the legal representative;

- The duty to take over tax from the transfer of property or similar tax.

Differences were then analysed and recommendation is in conclusion. 


\section{Discussions and Results}

\subsection{Cross-border mergers realized in the Czech Republic}

If we concentrate only on cross-border mergers carried out in the Czech Republic in the past few years, then there will not be many statistics. Cross-border mergers lead to the merging company, usually, changing into the permanent establishment which represents the company abroad, and it must fulfil certain requirements, which are demanded of it by the legal systems of both states. Doing business through a subsidiary, in comparison to this step, then, is much simpler. This is because the subsidiary simply comes under the legal order of the state in which it is situated. Information about the mutual joining of the companies provides consolidated financial statements, the preparation of which is a long-term standard approach, based on precise and clear rules (Roubíčková, 2011).

An indisputable advantage of doing business abroad through an permanent establishment, is the simplicity with which it can be established but frequent complication is insufficient accounting and tax adjustments for this form of business organisation, both in the state where the permanent establishment is actually situated, and the state from where it is directed (the seat of the successor company)

If we analyse those cross-border mergers carried out in the Czech Republic from 1st January 2008 to 31st December 2013; according to Tab. 1, it must be said that the number of mergers is very low. A similar number of cross-border mergers were also carried out in the Slovak Republic. According to recent research in this country, the annual number of cross-border mergers ranged from 7 to 14 mergers per year (Koba, 2013). 
Tab. 1: Development of Cross-Border Mergers in the Czech Republic in 2008-2013

\begin{tabular}{|c|c|c|c|c|c|c|}
\hline Calendar year & $\mathbf{2 0 0 8}$ & $\mathbf{2 0 0 9}$ & $\mathbf{2 0 1 0}$ & $\mathbf{2 0 1 1}$ & $\mathbf{2 0 1 2}$ & $\mathbf{2 0 1 3}$ \\
\hline $\begin{array}{c}\text { Number of mergers } \\
\text { noted in the Company } \\
\text { Register }\end{array}$ & 4 & 8 & 15 & 24 & 11 & 27 \\
\hline $\begin{array}{c}\text { Of which: completed in } \\
\text { the same year }\end{array}$ & 3 & 7 & 10 & 17 & 10 & 18 \\
\hline $\begin{array}{c}\text { Of which: completed in } \\
\text { the second year }\end{array}$ & 1 & 1 & 4 & 4 & 9 & 8 \\
\hline $\begin{array}{c}\text { Of which: completed in } \\
\text { the following years }\end{array}$ & 2 & 1 & 3 & 1 & 1 \\
\hline $\begin{array}{c}\text { Of which: not yet } \\
\text { completed }\end{array}$ & 4 & 9 & 14 & 21 & 19 & 26 \\
\hline $\begin{array}{c}\text { Published cross-border } \\
\text { mergers successfully } \\
\text { completed until 31 } \\
\text { August 2014 }\end{array}$ & 13 & 27 & 48 & 67 & 93 \\
\hline $\begin{array}{c}\text { Accumulated number of } \\
\text { cross-border mergers } \\
\text { successfully completed so } \\
\text { far }\end{array}$ & 4 & 1 & & & \\
\hline
\end{tabular}

Source: Schneiderová (2014).

Tab. 1 contains noted mergers and those mergers, which were successfully completed; i.e. registered in the Commercial Register. Some of the mergers, however, were not successfully completed. Tab. 1 contains all mergers; i.e. mergers of Czech companies, for which successor has legal jurisdiction in the Czech Republic and cross-border mergers, under which Czech companies cease to exist.

Following Tab. 2 includes information about mergers of companies from the Czech Republic abroad. Only realized mergers, which are registered in the Commercial Register are included in the table. 
Žárová, M. - Skálová, J.: Tax Aspects of Mergers and Cross-Border Mergers.

Tab. 2: Mergers of domestic companies abroad

\begin{tabular}{|l|c|c|c|c|c|c|c|}
\hline $\begin{array}{c}\text { Mergers from } \\
\text { the CZ abroad }\end{array}$ & $\mathbf{2 0 0 8}$ & $\mathbf{2 0 0 9}$ & $\mathbf{2 0 1 0}$ & $\mathbf{2 0 1 1}$ & $\mathbf{2 0 1 2}$ & $\mathbf{2 0 1 3}$ & $\begin{array}{c}\text { Total } \\
\text { nmber of } \\
\text { mergers }\end{array}$ \\
\hline Cyprus & 2 & 2 & & 2 & 1 & 2 & 9 \\
\hline Great Britain & 1 & & & & 1 & & 2 \\
\hline Germany & & 1 & 1 & 1 & & 1 & 4 \\
\hline Slovakia & & 2 & 4 & 3 & & 2 & 11 \\
\hline Netherlands & & 1 & & 1 & 1 & 1 & 4 \\
\hline Ireland & & 1 & & & & & 1 \\
\hline Luxemburg & & & & 1 & 1 & 1 & 3 \\
\hline Belgium & & & & 3 & & & 3 \\
\hline Italy & & & & 1 & 1 & 1 & 3 \\
\hline Austria & & & & & 1 & & 1 \\
\hline Liechtenstein & & & 5 & 13 & 7 & 8 & 43 \\
\hline Finland & & & & & 1 & & 1 \\
\hline $\begin{array}{l}\text { Total number } \\
\text { of mergers }\end{array}$ & 3 & 7 & & & & & 1 \\
\hline
\end{tabular}

Source: Schneiderová (2014).

In accordance with expectations, Czech companies mostly merge to its nearest neighbour country, into Slovakia. This fact confirms close Czech-Slovak trade relations, which stems both from a common history and from almost non-existent language barriers. Cyprus is in the second place, probably due to its tax-friendly environment. Germany and the Netherlands are shared with a third place.

Information about mergers of companies into the Czech Republic is shown in Tab. 3. It is necessary to emphasize that the number of mergers in the table contains not only the number of mergers realized "inside", but also a number of foreign companies being acquired, which could disappear in a merger even more companies at once. 
Tab. 3: Mergers of foreign companies into the Czech Republic

\begin{tabular}{|l|l|l|l|l|l|l|c|}
\hline $\begin{array}{c}\text { Mergers of } \\
\text { foreign } \\
\text { companies to } \\
\text { the CZ }\end{array}$ & $\mathbf{2 0 0 8}$ & $\mathbf{2 0 0 9}$ & $\mathbf{2 0 1 0}$ & $\mathbf{2 0 1 1}$ & $\mathbf{2 0 1 2}$ & $\mathbf{2 0 1 3}$ & $\begin{array}{c}\text { Total } \\
\text { number of } \\
\text { mergers }\end{array}$ \\
\hline Slovakia & & 2 & 5 & 3 & 10 & 13 & 33 \\
\hline Netherlands & & & 2 & 2 & & 2 & 6 \\
\hline Germany & & & 1 & & & & 1 \\
\hline Cyprus & 1 & & & & & & 7 \\
\hline France & & & 1 & & & & 4 \\
\hline Poland & & 1 & & & 2 & & 4 \\
\hline Hungary & & & & & & 1 & 1 \\
\hline Luxemburg & 1 & 3 & 10 & 9 & 15 & 23 & 61 \\
\hline Austria & & & & & 1 & 1 \\
\hline Bulgaria & & & & & 1 & 3 \\
\hline Croatia & & & & & & \\
\hline Total & & & & & & & \\
\hline
\end{tabular}

Source: Schneiderová (2014).

\subsection{Tax aspects of mergers}

Directive 90/434/EC sets the conditions for mergers, business investment and exchange rate of shares. It also applies to the joint taxation system for mergers, split of companies, transfers of assets and the exchange rate of shares concerning companies from different member states. Directive 90/434/EC was amended several times and it was replaced by Directive 2009/133/EC of 19 October 2009, with the same structure of articles as the previous one. References in the text are the same for both Directives (Directive on mergers).

The Czech law No.438/2003 Coll. transposed this Directive upon the Czech Republic's accession to the EU. It applies even to domestic mergers, including merger of parent companies and subsidiaries. The Directive also delineates the types of companies, which it applies to. Generally, it concerns companies kept in portfolios (as a rule, capital 
portfolios), which do not have the possibility of tax relief for legal entities and are considered to be tax residents of the EU.

However, transposition of this Directive brought an advantage for Czech companies; namely, the possibility of taking over tax losses among capital companies since 2004. The Directive requires this advantage in cross-border transactions; the possibility of taking over the losses among domestic companies is a great advantage (Skalova, Mejzlík 2012).

The basic principle of tax neutrality is contained in Article 4 of the Directive. The Czech Republic has chosen the tax continuity principle; i.e., not taxing capital gains at company or partner level. Revaluation of assets and liabilities at fair values, carried out during mergers and included in the accounts among the liabilities as an increase in own capital, does not have any tax consequences. The tax value of the merging company's assets is carried over to the successor company and they are used in other tax judgments, in transactions with assets (sale, tax depreciations). This method was chosen not only for cross-border mergers (as stipulated by the Directive), but also for domestic mergers.

We have chosen research results on tax aspects of domestic mergers those represents fundamentals for cross-border mergers, summarised in Tab. 4. From the judicial acts of ECJ, it is evident, that it is forbidden to use some advantages for domestic transactions. As many courtiers would like to avoid problems, rules from Directive are transposed identically for domestic operations and for cross-border ones. Differences between member states are illustrated in Tab. 4.

Tab. 4: Internal tax conditions for mergers

\begin{tabular}{|c|c|c|}
\hline What, from the point & $\begin{array}{c}\text { Wharing a merger, is it possible } \\
\text { of view of income tax, } \\
\text { is revaluation in } \\
\text { domestic mergers? }\end{array}$ & $\begin{array}{c}\text { During } \\
\text { to take over tax losses to the } \\
\text { successor company, in a } \\
\text { domestic merger, and under } \\
\text { what conditions? }\end{array}$ \\
\hline Belgium & $\mathrm{n} / \mathrm{a}$ & $\begin{array}{c}\text { Yes, it can be used by successor } \\
\text { companies only against the sum of } \\
\text { the ,taxable base“ of each of the } \\
\text { companies, which the given } \\
\text { company has in total after the } \\
\text { merger }\end{array}$ \\
\hline
\end{tabular}




\begin{tabular}{|c|c|c|}
\hline & $\begin{array}{l}\text { What, from the point } \\
\text { of view of income tax, } \\
\text { is revaluation in } \\
\text { domestic mergers? }\end{array}$ & $\begin{array}{l}\text { During a merger, is it possible } \\
\text { to take over tax losses to the } \\
\text { successor company, in a } \\
\text { domestic merger, and under } \\
\text { what conditions? }\end{array}$ \\
\hline $\begin{array}{l}\text { Czech } \\
\text { Republic }\end{array}$ & $\begin{array}{l}\text { Not relevant for tax } \\
\text { purposes }\end{array}$ & $\begin{array}{l}\text { Yes, under the condition that: it is } \\
\text { for five tax periods at most, losses } \\
\text { are linked to the activities of the } \\
\text { merging company (if the } \\
\text { successor company does not } \\
\text { perform the activities of the } \\
\text { merging company, it is not } \\
\text { possible to carry over the losses) } \\
\text { and the purpose of the merger } \\
\text { should not be the reduction, or } \\
\text { avoidance, of tax obligations }\end{array}$ \\
\hline France & $\begin{array}{l}\text { It is relevant for tax } \\
\text { purposes (tax } \\
\text { depreciations from new } \\
\text { prices, revaluation } \\
\text { considered as taxable } \\
\text { income); it is possible to } \\
\text { apply Article } 210 \text { of the } \\
\text { tax law and not pay tax } \\
\text { on the revaluation }\end{array}$ & $\begin{array}{l}\text { Yes, but the successor must carry } \\
\text { out the activity }\end{array}$ \\
\hline Cyprus & $\begin{array}{l}\text { It is not tax relevant (tax } \\
\text { depreciation continues } \\
\text { from the original prices } \\
\text { used for tax purposes) }\end{array}$ & Yes, without further limitations \\
\hline Hungary & $\begin{array}{l}\text { It is tax relevant (tax } \\
\text { depreciation from the } \\
\text { new prices, revaluation } \\
\text { is considered to be } \\
\text { taxable income); the } \\
\text { exception is the } \\
\text { "preferential merger" }\end{array}$ & Yes, without further limitations \\
\hline Norway & $\begin{array}{l}\text { It is not tax relevant (tax } \\
\text { depreciation continues } \\
\text { from the original prices } \\
\text { used for tax purposes) }\end{array}$ & $\begin{array}{l}\text { Yes, if the expired company } \\
\text { carries on doing business }\end{array}$ \\
\hline
\end{tabular}


Žárová, M. - Skálová, J.: Tax Aspects of Mergers and Cross-Border Mergers.

\begin{tabular}{|c|c|c|}
\hline & $\begin{array}{l}\text { What, from the point } \\
\text { of view of income tax, } \\
\text { is revaluation in } \\
\text { domestic mergers? }\end{array}$ & $\begin{array}{l}\text { During a merger, is it possible } \\
\text { to take over tax losses to the } \\
\text { successor company, in a } \\
\text { domestic merger, and under } \\
\text { what conditions? }\end{array}$ \\
\hline Poland & $\begin{array}{l}\text { It is not tax relevant (tax } \\
\text { depreciation continues } \\
\text { from the original prices } \\
\text { used for tax purposes) }\end{array}$ & No \\
\hline Austria & $\begin{array}{l}\text { It is not tax relevant (tax } \\
\text { depreciation continues } \\
\text { from the original prices } \\
\text { used for tax purposes) }\end{array}$ & $\begin{array}{l}\text { Yes, on condition that the } \\
\text { successor takes over the carrying } \\
\text { values of the merging company; } \\
\text { the losses of the merging } \\
\text { company must be compatible with } \\
\text { the business taken over/ taken } \\
\text { over assets - must exist to the } \\
\text { decisive day; loss is useful only to } \\
\text { the extent that the business/asset } \\
\text { from which it arose, exists to the } \\
\text { decisive day. }\end{array}$ \\
\hline Romania & $\begin{array}{l}\text { It is not tax relevant (tax } \\
\text { depreciation continues } \\
\text { from the original prices } \\
\text { used for tax purposes) }\end{array}$ & $\begin{array}{l}\text { No, only the successor company } \\
\text { can use tax losses }\end{array}$ \\
\hline Slovakia & $\begin{array}{l}\text { Companies have the } \\
\text { right to choose. } \\
\text { Valuation is either not } \\
\text { tax relevant, and then it } \\
\text { continues from the } \\
\text { original prices, or it is } \\
\text { tax relevant; the } \\
\text { difference between } \\
\text { original and new prices } \\
\text { comes under income tax. }\end{array}$ & $\begin{array}{l}\text { Yes, on condition the following } \\
\text { consecutive tax periods do not } \\
\text { exceed } 7 . \text { The purpose of the } \\
\text { merger may not be the reduction, } \\
\text { or avoidance, of tax duties. }\end{array}$ \\
\hline
\end{tabular}

Sources: Authors' own research.

The Directive is meant for those situations where, in a cross-border merger, the property remains in the state where the original merging company was situated. The Directive does not envisage the shift of 
property from one state to another, and neither, therefore, the situation where the original state would lose the possibility of taxing the profits gained from carrying out the activities of the expired company. This subject will remain in the territory of the original state. Its business activities, however, will take the legal form of a foreign permanent establishment. For tax purposes it will still be run as an income tax payer.

\subsection{Approaches to take over tax losses from abroad}

Using the Directive on Merger obliges Member States to apply the Directive to all states, if they involve companies from different Member States. Directive, Article 6, provides that if the Member State would apply provisions allowing the receiving company to take over the losses of the transferring company which had not yet been exhausted for tax purposes, it shall extend those provisions to cover the takeover of such losses by the receiving company's permanent establishments situated within its territory. This article, however, does not provide that it would be necessary that the loss of the acquired company is always taken by the acquiring company.

1. The problem is that this rule can be transposed into national legislations of EU member states in different ways: Possibility to take over the loss of the dissolved company whether domestic or foreign, without limitation whether it is a subsidiary or equity unrelated company (e.g. Czech Republic).

2. Possibility to take over the loss of the dissolved company but only of the domestic one (e.g. Finland).

3. The ability to take over the loss of the acquired company is forbidden (e.g. Poland).

The Czech Republic transposed provision into the Act on income tax that the acquiring company can take a tax loss company being acquired, whether this will be the company acquired domestic or foreign one. They are thus ensured equal rights to tax residents and non-residents.

The possibility to take over tax loss is opposed by the rule that permits withdrawal of the benefits of the Directive. Companies may be withdrawn the benefits of the Directive if it is apparent that the merger is aimed at reducing or avoiding the tax liability and there are no proper economic reasons for the merger. Article 11 of the Directive has almost identical wording as the Czech Income Tax Act: "A Member State may refuse to apply or withdraw the benefit of all or any part of the provisions of Titles 
Žárová, M. - Skálová, J.: Tax Aspects of Mergers and Cross-Border Mergers.

II, III and IV where it appears that the merger, division, transfer of assets or exchange of shares has as its principal objective or as one of its principal objectives tax evasion or tax avoidance. The fact that one of the operations referred to in Article 1 is not carried out for valid commercial reasons such as the restructuring or rationalization of the activities of the companies participating in the operation may constitute a presumption that the operation has tax evasion or tax avoidance as its principal objective or as one of its principal objectives."

A judgment of the European Court of Justice (hereinafter the ECJ) was given in this matter on 10 November 2011.

Judgment of the Court (Fifth Chamber) of 10 November 2011, C126/10 Foggia - Sociedade Gestora de Participações Sociais SA vs. Secretário de Estado dos Assuntos Fiscais.

This was a Portuguese case where the Portuguese Tax Code stipulates that a tax loss of the dissolving company is transferrable to the successor company provided that consent has been granted by the Minister of Finance. This consent was denied on the ground that, in the opinion of the Ministry of Finance, the merger had not been made for valid commercial reasons. The affected company brought the case before court. The Portuguese court referred the following questions to the ECJ for a preliminary ruling because the matter involved provisions of national legislation, which follow from Directive 90/434/EEC on a common system of taxation applicable to mergers.

The questions were formulated as follows:

1. What are the meaning and effect of Article 11(1) (a) of Directive [90/434] and, in particular, what is the meaning of "valid commercial reasons" and "restructuring or rationalisation of the activities" of companies participating in operations covered by Directive [90/434]?

2. Is the view taken by the tax authorities, that there are no serious commercial reasons for the acquiring company's request to transfer tax losses, leading them to conclude that, from the acquiring company's point of view, there was no apparent commercial interest in acquisition, since the acquired company had developed no activity as a holding company and had no financial holdings, and would consequently transfer only substantial losses, although the merger might represent a positive effect in terms of 
the cost structure of the group, compatible with that provision of Community law?

Consequently, the Court's conclusion reads as follows:

1. The cost savings resulting from the reduction of administrative and management costs, when the acquired company disappears, is inherent in any operation of merger by acquisition as this implies, by definition, a simplification of the structure of the group of companies.

2. By automatically accepting that the saving in the cost structure resulting from the reduction of the administrative and management costs constitutes a valid commercial reason, without taking account of the other objectives of the proposed operation, and particularly the tax advantages, the rule set out in Article 11(1)(a) of Directive 90/434 ${ }^{1}$ would be entirely deprived of its purpose, which consists in safeguarding the financial interests of the Member States by providing, in accordance with the ninth recital in the preamble to that directive, the option for those Member States to refuse the benefit of the provisions laid down by the directive in the event of tax evasion or avoidance.

Article 11(1)(a) of Directive 90/434 reflects the general principle of EU law that abuse of rights is prohibited - that is to say, transactions carried out not in the context of normal commercial operations, but solely for the purpose of avoiding the rules provided for by that law.

The answer to be given to the question submitted must therefore be that Article 11(1)(a) of Directive 90/434 is to be interpreted as meaning that, in the case of a merger operation between two companies of the same group, the fact that, on the date of the merger operation, the acquired company does not carry out any activity, does not have any financial holdings and transfers to the acquiring company only substantial tax losses of undetermined origin, even though that operation has a positive effect in terms of cost structure savings for that group, may constitute a presumption that the operation has not been carried out for 'valid commercial reasons'. It is incumbent on the national court to verify, in the light of all the circumstances of the dispute on which it is required to rule, whether the constituent elements of the presumption of

1 The rule provides that a Member State may refuse the benefit where it appears that the merger has as one of its principal objectives tax evasion or tax avoidance. 
Žárová, M. - Skálová, J.: Tax Aspects of Mergers and Cross-Border Mergers.

tax evasion or avoidance, within the meaning of that provision, are present in the context of that dispute.

The Portuguese Government sought to raise a plea claiming a lack of jurisdiction of the ECJ on the ground that the context of the main proceedings is purely national. However, the ECJ adopted an opinion that where both national and cross-border transactions take place in Portugal according to the same tax regime, than it is clearly in the European Union's interest that, in order to forestall future differences of interpretation, provisions or concepts taken from EU law should be interpreted uniformly, irrespective of the circumstances in which they are to apply.

With regard to Section 23d (2) of the Czech Income Tax Act, as amended, which reflects implementation of the above discussed provision of the EU Directive into the Czech environment, this Court's decision can also be applied to Czech cases of mergers.

In a number of business groups there is a loss-reporting company because the project, which it was established for, was simply unsuccessful. As a result, loss thus usually arose on account of regular overhead expenses of the company and often also by writing off a frustrated investment if investments were already made in a pre-project preparation of e.g. real property which wasn't subsequently built. The management of the group usually considers what to do with such a company - use it for a new project, liquidate it or implement a merger with another group company? It is thus necessary to newly reflect the conclusions from the above decision of the ECJ in these considerations. Consequently, there must be valid economic reasons for a merger. Mere savings in administrative costs within the group will not suffice as ground for a merger.

\subsection{Possibility to deny benefits from other tax}

One of some other interesting case-law of the ECJ, it is worth recalling the judgment published by the ECJ under the title C-352/08 in the Zwijnenburg case of 20 May 2010. It involved a Dutch case.

The Zwijnenburg family intended to perform a merger of family businesses; son, through its company, operated a clothes shop, which was located in two buildings. One of the buildings was owned by the father (through his company) who rented it to his son. The goal was to merge both buildings (both companies) into one company and the son later intended to acquire also his father's share. The Zwijnenburg family 
requested the Netherlands Tax Authority to confirm that the proposed company merger and the subsequent acquisition of shares could be carried out without taxation.

The Netherlands Tax Authority turned down that request - the envisaged merger of the buildings into one company is based on reasonable economic reasons but the merger of companies (selected for merger of the buildings) is designed only to avoid the real estate transfer tax.

The Netherlands Property Transfer Tax Act provides that acquisition of real property through merger is exempt from tax. The Netherlands Income Tax Act provides that profit made through a merger does not constitute tax liability but this profit is subject to taxation if the merger is predominantly designed to avoid or defer taxation.

The Netherlands Tax Authority states that in case of a merger there is no possibility of denying exemption from real estate transfer tax and so, instead of the unpaid real estate transfer tax; an income tax is levied with reference to tax avoidance.

The Netherland court dealt with the Council Directive 90/434/EEC that stipulates income tax benefits during these operations. However, pursuant to Article 15, the benefits of the Directive may be withdrawn if the operation had as its principal objective tax avoidance. Does that mean only avoidance of income tax or also avoidance of other taxes such as real estate transfer tax?

Consequently, the following questions were referred to the European Court of Justice for a preliminary ruling:

1. Must Article 15 of Directive be interpreted as meaning that the benefits of that Directive may be withheld from a taxpayer where a series of legal transactions is aimed at preventing the levying of a tax other than the taxes which the benefits set out in that Directive relate to?

2. Can Article 15 of the Directive be applied to avoidance of real estate transfer tax?

Again, the ECJ first made a decision on admissibility of the preliminary ruling. The main objective of the Directive is to eliminate tax barriers to cross-border transactions. The Zwijnenburg family case was only a national merger. However, the Netherlands transposed the Directive into its national legislation and applies it also to national 
situations - treats cross-border and national mergers equally. It is the European Union's interest that provisions taken from EU law should be interpreted uniformly and so the preliminary ruling is admissible.

The ECJ provided the following assessment of the case: "Article 11 represents an exception from application of the Directive and must be subject to strict interpretation and reviewed on a case-by-case basis. The Directive only refers to taxes relating to transactions according to the Directive - to taxes encumbering the company or shareholders. There is no indication that it would refer to real estate transfer tax. In addition, direct taxation does not come within the remits of the EU and real estate transfer tax is always within the remits of the Member State."

Ruling of the Court:

"Article 11(1)(a) of Council Directive 90/434/EEC of 23 July 1990 on the common system of taxation applicable to mergers, divisions, transfers of assets and exchanges of shares concerning companies of different Member States is to be interpreted as meaning that the favourable arrangements which the directive introduces may not be withheld from a taxpayer who has sought, by way of a legal stratagem involving a company merger, to avoid the levying of a tax such as that at issue in the main proceedings, namely transaction tax, where that tax does not come within the scope of application of that directive."

The conclusions following from this decision can also be applied in the Czech environment because both the previous Real Estate Transfer Tax Act and the currently applicable Real Estate Acquisition Tax Act exempts the transfer of real estate implemented through a merger or division of the company.

In transfers of large volumes of real estate the amount of $4 \%$ is no longer negligible and it may be appropriate to use merger for implementation of certain transfers of property rather than e.g. sale of the real estate or contribution to the registered capital or equity capital which is not exempt from real estate acquisition tax from 1 January 2014.

\subsection{Possibility of transfer of tax loss from abroad}

The Council Directive 2009/133/EC does not impose an obligation on the Member States to incorporate into their legislation the possibility of takeover of the loss by the successor company after merger. However, if the Member States incorporates such obligation, Article 6 of the Directive provides that if the Member State allows the receiving (successor) 
company to take over the losses of the transferring company which had not yet been exhausted for tax purposes, it shall extend those provisions to cover the takeover of such losses by the receiving company's permanent establishments situated within its territory.

If we look at the individual Member States, we can clearly see that the regulation is quite heterogeneous.

In the Czech Republic, the transfer of losses from the dissolving company to the successor company is allowed provided that there are appropriate economic reasons for the merger. The successor company or permanent establishment may apply this tax loss only against the same activities from which the tax loss arose.

In Romania and Poland, tax loss cannot be transferred from the dissolving company to the successor company. However, the successor company may apply its tax loss even after the merger. In Norway, it is possible to transfer the tax loss to the successor company under the precondition that the successor company takes over also the activity of the dissolving company, which the tax loss arose from. In Hungary and Cyprus, it is possible to transfer the tax loss in the framework of the merger without further limitations.

In Slovakia, it is possible to transfer the tax loss from the dissolving company to the successor company unless the merger is aimed at reducing or avoiding the tax liability.

As mentioned above, the Czech Republic implemented a provision in its Income Tax Act that the successor company may take over the tax loss of the dissolving company, whether it is a domestic or foreign dissolving company. This ensures equal rights for both tax residents and nonresidents.

The fact that not all EU countries take the same approach is also indicated by the case-law of the European Court of Justice; different approach to mergers with domestic subsidiary as opposed to foreign subsidiary is particularly evidenced by judgment A Oy Case C-123-11.

The given case involved a dissolving Swedish company, which represented a subsidiary of a Finnish parent company. The Finnish Income Tax Act does not allow takeover of a tax loss by the parent company if the registered office of the dissolving subsidiary is located in some other EU country. By contrast, takeover of the tax loss is allowed in case of a merger with domestic company. The Finnish parent company sought the possibility to take over the tax loss from its dissolving 
subsidiary company. In the court proceedings, the Finnish court then referred to the European Court of Justice with two questions:

1. Do Articles 49 TFEU and 54 TFEU require that a receiving company may, in the context of its taxation, deduct the losses of a company which was resident in another Member State and which has merged with the receiving company, when those losses arise from the merged company's activity there in the years prior to the merger and when the receiving company has no permanent establishment in the State of residence of the merged company and, under national law, the receiving company may deduct losses of the merged company only if the latter is a resident company or the losses arose in the permanent establishment situated in that State?

2. If the answer to the first question is in the affirmative, do Articles 49 TFEU and 54 TFEU have a bearing on whether the loss to be deducted is calculated in accordance with the tax legislation of the receiving company's State of residence, or should the losses ascertained pursuant to the law of the State of residence of the company which is to be merged be considered as deductible losses?

The answer of the ECJ to the first question is:

1. Articles 49 TFEU and 56 TFEU do not, in the circumstances of the main proceedings, preclude national legislation under which a parent company merging with a subsidiary established in another Member State, which has ceased activity, cannot deduct from its taxable income the losses incurred by that subsidiary in respect of the tax years prior to the merger, while that national legislation allows such a possibility when the merger is with a resident subsidiary. Such national legislation is none the less incompatible with European Union law if it does not allow the parent company the possibility of showing that its non-resident subsidiary has exhausted the possibilities of taking those losses into account and that there is no possibility of their being taken into account in its State of residence in respect of future tax years either by itself or by a third party.

By virtue of settled case-law, a restriction on the freedom of establishment is permissible only if it is justified by overriding reasons in 
the public interest. Such justification, according to the settled case-law, may consist in maintaining the allocation of the power to impose taxes between the Member States. Accordingly, the Member States may adopt measures aimed at safeguarding the exercise of their powers of taxation. To this end, it may be necessary to apply to the economic activities of companies established in one of those Member States only the tax rules of that Member State in respect of both profits and losses.

The power of taxation of a Member State is jeopardised by taking account of the losses, which arose in the framework of exclusive power of taxation of another Member State. The losses taking account of which is the subject of the deliberated case arose as a result of activity of a Swedish company in Sweden. Pursuant to Article 7 (1) of the double taxation avoidance agreement to be applied in the deliberated case, this activity is subject to exclusive power of taxation of the Kingdom of Sweden. Taking account of these losses would thus jeopardise the power of taxation of Finland. The Republic of Finland would take account of the losses from activity it cannot make subject to tax liability. Consequently, the Republic of Finland is in this respect basically entitled to prevent a taxable person from taking account of the losses of the Swedish subsidiary. ${ }^{2}$.

The above Advocate General's Opinion was concurred in also by the Governments that have submitted observations to the Court of Justice. They take the view that difference in treatment at issue in the main proceedings is justified by the need to safeguard the allocation of the power to impose taxes between the Member States and to avert the risks of the double use of losses and tax avoidance.

Justification of different treatment of residents and non-residents may be allowed, where the set tax system is designed to prevent conduct liable to jeopardise the right of a Member State to exercise its powers of taxation in relation to activities carried on in its territory (see, to that effect, judgment of 29 March 2007, Rewe Zentralfinanz, C-347/04, ECR I-2647, paragraph 42, and the above judgment Oy AA, paragraph 54).

Preservation of the allocation of the power to impose taxes between Member States might make it necessary to apply to the economic activities of companies established in one of those States only the tax rules of that State in respect of both profits and losses. To give companies

2 Opinion of the Advocate General JULIANE KOKOTT presented on 19 July 2012 in the case C-123/11 A Oy, paragraphs 43, 44. 
the right to elect to have their losses taken into account in the Member State in which they are established or in another Member State would seriously undermine a balanced allocation of the power to impose taxes between the Member States in that the taxable bases would be altered in both States to the extent of the losses transferred.

As regards, finally, the risk of tax avoidance, the possibility of transferring the losses of a non-resident subsidiary to a resident company on the occasion of a merger entails the risk that that sort of restructuring will be organised within a group of companies so that the losses are taken into account in the Member States which apply the highest rates of tax and in which the tax value of the losses is therefore the highest.

In the light of these factors, it must be accepted that legislation of a Member State under which a parent company established in that Member State is denied the possibility of deducting from its taxable income the losses of the merged subsidiary established in another Member State, first, pursues legitimate objectives and is justified by overriding reasons in the public interest.

The answer to the second question is important also for the Czech taxpayers because the Czech Income Tax Act contains provision on takeover of foreign tax loss.

The answer of the ECJ to the second is:

2. The rules for calculating the non-resident subsidiary's losses for the purpose of their being taken over by the resident parent company, in an operation such as the merger at issue in the main proceedings, must not constitute unequal treatment compared with the rules of calculation, which would be applicable if the merger were with a resident subsidiary.

The answer to the second question thus means that calculation of the amount of applicable loss must be "reviewed" according to domestic tax rules which regulate e.g. the amount of tax depreciation, possibility of tax recognition of interest on credit provided by an affiliate or take into account the possibility of creation of tax deductible reserves.

In this part, the ECJ fully agreed with the Advocate General who stated: In my view, the reply to the second question should then be that the losses to be taken into account must in principle be calculated according to the tax law of the receiving company's State of residence. As the French Government also submitted, only in that way would calculation of the losses lead to equal treatment in cases within a single 
Member State and in cross-border situations, that is to say, a merger with a resident subsidiary and a merger with a foreign subsidiary would receive equal treatment for tax purposes. The principle that the losses to be taken into account must be calculated according to the tax law of the receiving company's State of residence may be limited, depending on the cause of a loss calculation differing from the operating result. Exceptions could apply, for example, for fiscal promotion measures of the receiving company's State of residence, such as higher depreciation, which result in a bigger loss. It could be justifiable to limit the application of such measures just for domestic activities. The consequence of this would be that to that extent losses would not have to be calculated according to the tax law of the receiving company's State of residence.

\section{Conclusion}

Using Directive on mergers obliges Member States to apply the Directive to all states, if companies from different Member States involve the merge. Directive on Mergers, Article 6, provides that if the Member State would apply provisions allowing the receiving company to take over the losses of the transferring company which had not yet been exhausted for tax purposes, it shall extend those provisions to cover the takeover of such losses by the receiving company's permanent establishments situated within its territory. Article 6, however is not transposed into national legislations of EU member states in the same way. It is evident, that regulation by Directives might bring disadvantages because transposition of Directive into legislative of EU member states could differ. In such cases, European Court of Justice is asked for treatment.

The European Court of Justice examines in its judgments, in particular, whether the tax legislation of a State is in contrary to the freedom of establishment, i.e. whether the freedom of establishment is not limited. According to case law, restrictions on freedom of establishment are permitted if it is justified by overriding reasons in the general interest. It may consist in preserving the allocation of tax jurisdictions between Member States. This tax jurisdiction of a particular state is threatened by taking into account the losses incurred in another Member State. Acquiring company in its taxation cannot deduct tax losses of foreign companies.

From the judicial act A Oy C-123/11 follows the conclusion that EU law does not preclude such a solution in national tax system, under which domestic successor company in its taxation cannot deduct tax losses to a 
foreign company, which has merged and it is its legal successor. Foreign tax losses arising in the jurisdiction of another Member State and the State acquiring company may not disregard it. If the company decided to take into account tax loss and it allows tax deduction, then this loss must be fundamentally calculated in accordance with the tax regulations. This tax loss will be calculated at a level that would have been shown by a domestic taxpayer in accordance with domestic tax law. This approach ensures equal treatment of domestic and foreign cases.

As the Directive ensures equal treatment of domestic mergers and cross-border ones, majority of countries developed the same economic and law conditions in order to realize domestic mergers and cross-border ones equally. This approach has been developed in order to realise equal conditions for running business for all entities. As it is seemed from the research, accounting and tax aspects of domestic mergers and crossborder ones in the Czech Republic are therefore the same.

\section{References}

Bech-Brunn, L. (2013): Study on the Application of the Cross-border Merger Directive [on-line]. Lexidale, 2013, 19. 3. 2014. [cited $3^{\text {rd }}$ October 2014], <http://ec.europa.eu/internal_market/company/docs/ mergers/131007_study-cross-border-merger-directive_en.pdf.>

Berhens F. O. (2007): Die grenzüberschreitende Verschmelzung nach der Richtlinie 2005/56/EG. Göttingen: Cuvillier Verlag, 2007.

Coeurdacier, N. De Santis, R., Aviat, A. (2009): Cross-border mergers and acquisitions; financial and institutional forces [on-line]. Praha: 19. 3. 2014, [cited $3^{\text {rd }}$ October 2014], <http://www.ecb.europa.eu>, <http://ssrn.com/abstractid=1336488>.

Directorate General for the Internal Marktet and Service the European Union [on-line]. 2013, 19. 3. 2014, [cited $3^{\text {rd }}$ October 2014], <http://ec.europa.eu/dgs/internal_market/index_en.htm>

Ištvánfyová, J. - Mejzlík, L. (2009): Trends of Financial Reporting in Czech Republic and Its Regulation. Acta Aerarii Publici, 2009, vol. 6, no. 2, pp. 15-25.

Knuppel, M. (2007): Bilanzierung von Verschmelzungen nach Handelsrecht, Steuerrecht und IFRS. Berlin: Erich Schmidt Verlag, 2007.

Koba, P. (2013): International Mergers in Slovakia - Legal, Accounting and Taxation Forms (In Czech: Přeshraniční fúze na Slovensku - právní, 
účetní a daňová úprava) [on-line], [cited $3^{\text {rd }}$ October 2014], $<$ http://isis.vse.cz/zp/index.pl>

Kulenkamp, S. (2009): Die grenzüberschreitende Verschmelzung von kapitalgesellschaften in der EU. Baden-Baden: Nomos, 2009, 393 pp.

Oestreicher, A. - Koch, R. (2010): Taxation and Corporate Group Structure - Evidence from a Panel of European Multinationals. Istanbul 2010 EAA Congress, 19. - 21. 5. 2010.

Pelák, J. (2010): Valuation Prospective of Merger Accounting of Deferred Tax (In Czech: Problematika odložené daně ve fúzich z pohledu oceňováni a účetnictví). Český finanční a účetní časopis, 2010, vol. 5, no. 4, pp. 101-107.

Roubíčková, J. (2011): Question Marks over the Foreign Entities in the Czech Law. In: Managing Services in the Knowledge Economy 2011. Famalicao, 13.07.2011 - 15.07.2011. Famalicao: Universidade Lusíada de Vila Nova de Famalicao, 2011, pp. 84-92.

Skálová, J. - Mejzlík, L. (2012): Cross-Border Mergers in the European Union. American International Journal of Contemporary Research (AIJCR), 2012, vol. 2, no. 4, pp. 6-17.

Sklenár, R. - Roubíčková, J. (2011): Identification of Several Important Factors According to Cross-Border Mergers: Focused on the Czech Republic. In: Finance and the Performance of Firms in Science, Education and Practice. Zlín: UniverzitaTomáše Bati, 2011, pp. 408-422.

Schneiderová, L. (2014): Cross-Border Mergers (In Czech: Přeshraniční fúze) [on-line], [cited $3^{\text {rd }}$ October 2014], 〈http://isis.vse.cz/zp/index.pl>

Trnka, M. - Dugová, A. (2012): Cross-border mergers with the Czech domiciled companies [on-line], [cited $3^{\text {rd }}$ October 2014] <http://macrotheme.com/yahoo_site_admin/assets/docs/9MR31ADu.1335 141.pdf >

Vítek, L. (2014): Corporate Taxation in the EU between 1995 - 2012: Convengence or Divergence? In: Špalková, D. - Matějová, L. (ed.). Proceedings of the 18th International Conference. Current Trends in Public Sector Research. Brno, Masarykova univerzita, 2014, pp. 99-106.

Vomáčková, H. (2012): Development of Accounting Treatment of Transformations of business companies and Cooperatives over the Past Twenty Years (In Czech: Vývoj účetního rešeni preměny obchodnich společností a družstev za poslednich dvacet let). Český finanční a účetní časopis, 2012, vol. 7, no. 1, pp. 33-51. 
Žárová, M. - Skálová, J.: Tax Aspects of Mergers and Cross-Border Mergers.

Žárová, M. (2006): Regulation of European Accounting (in Czech: Regulace evropského účetnictví.) Praha: Nakladatelství Oeconomica, 2006, pp. 184.

Žárová, M. (2008): Accounting Reform in the Czech Republic. In: MCGEE, Robert W. Accounting Reform in Transition and Developing Economies. Miami: Springer, 2008, pp. 89-100, pp. 600.

Žárová, M. - Skálová, J. (2012): Obstacles in European Union Crossborder Mergers Realization (Překážky při realizaci přeshraničních fúzí v Evropské unii). Současná Evropa, 2012, vol. XVII, no. 02, pp. 83-104.

Žárová, M. (2013): Can the Academic Research Contribute to the Legislative Change in Accounting Topics? In: Jirčíková, E. - Knápková, A. - Pastuszková, E. (ed.). Finance and the Performance of Firms in Science, Education, and Practice - Proceedings of the 6th International Scientific Conference. Zlín: Univerzita Tomáše Bati ve Zlíně, 2013, pp. 827-836. 


\title{
Tax Aspects of Mergers and Cross-Border Mergers
}

\begin{abstract}
The paper concentrates on tax aspects of merger with a special attention to cross-border ones. Despite the fact that Directive, which set the conditions for mergers, business investment and exchange rate of shares, was issued 24 years ago, unified treatment of tax aspects hasn't been reached yet. This paper is based on research of tax rules transposed from Tax Merger Directive, 83 into law systems of EU member states. This Directive was used for tax treatment of domestic mergers as for crossborder ones. Although the Directive has been transposed, there are differences in tax treatment among member states. The paper shows inability of solving the problem by Directive as coordination of the tax and legal regime of several jurisdictions are usually not adapted to each other and examples when the European Court of Justice is asked for treatment. Different approaches to discussed issues are presented in the paper.
\end{abstract}

Key words: Cross-border mergers; Tax aspects; Take over losses.

JEL classification: $\mathrm{H} 25, \mathrm{H} 32$ 